\title{
Maternal thyroid status regulates the expression of neuronal and astrocytic cytoskeletal proteins in the fetal brain
}

\author{
D Sampson, M R Pickard, A K Sinha, I M Evans, A J Leonard \\ and $\mathbf{R} \mathbf{P}$ Ekins
}

Division of Molecular Endocrinology, University College London Medical School, Mortimer Street, London W1N 8AA, UK

(Requests for offprints should be addressed to A K Sinha)

\begin{abstract}
Maternal thyroid hormone (TH) crosses the placenta and is postulated to regulate fetal brain development. However, TH-dependent stages of fetal brain development remain to be characterised. We have therefore compared the levels of several neuronal and glial cytoskeletal proteins in fetal brains from normal $(\mathrm{N})$ and partially thyroidectomised (TX) rat dams by immunoblotting. Pregnancies were studied both before and after the onset of fetal $\mathrm{TH}$ secretion, which occurs at $\mathbf{1 7 \cdot 5}$ days gestation $(\mathrm{dg})$ in the rat.

Maternal hypothyroidism disrupted fetal growth, so that fetal body and brain weights were reduced near term. Vimentin expression was unaffected, however, indicating normal acquisition of neuronal and glial precursor cells. Fetal brain levels of glial fibrillary acidic protein (GFAP) were reduced at $21 \mathrm{dg}$, suggesting delayed astrocytic
\end{abstract}

differentiation, although regression analysis demonstrated appropriate GFAP levels for brain weight. Levels of $\alpha$-internexin, the earliest neurofilament protein expressed in fetal brain were reduced at $16 \mathrm{dg}$ in TX dams, but increased at $21 \mathrm{dg}$. The ontogeny of neurofilament-L was also perturbed in these pregnancies, with deficient levels apparent at both 16 and $21 \mathrm{dg}$. These effects on neuronal cytoskeletal proteins were unrelated to fetal brain growth retardation.

These findings confirm that maternal hypothyroidism disrupts early fetal brain development. Early disturbances in neuronal differentiation are not corrected by the onset of fetal TH secretion. Such disturbances may contribute to the neurological damage observed in children born to hypothyroxinaemic mothers.

Journal of Endocrinology (2000) 167, 439-445

\section{Introduction}

Maternal thyroid hormone ( $\mathrm{TH})$ is transferred to the fetus throughout pregnancy and is postulated to regulate early fetal brain development (Porterfield \& Hendrich 1991, Morreale de Escobar et al. 1997, Pickard et al. 1997, Sinha et al. 1997). In humans, maternal hypothyroidism during pregnancy is associated with impaired cognitive and motor function in children (Man et al. 1991, Haddow et al. 1999). Even in healthy pregnancies, infant neurodevelopment correlates directly with maternal plasma free thyroxine $\left(T_{4}\right)$ levels during the first trimester (Pop et al. 1999). Field studies in the iodine-deficient endemias have also emphasised the importance of maternal thyroid status before the onset of fetal $\mathrm{TH}$ synthesis with respect to neurological and intellectual development of the offspring (Connolly \& Pharoah 1989).

The influence of thyroid hormone on brain development has been extensively investigated in cell culture and in vivo models of congenital hypothyroidism (Bernal \& Nunez 1995). Thyroid hormone regulates most - if not all-stages of neuronal and glial cell development. Consequently, congenital hypothyroidism is associated with disturbed expression of neuronal and glial cellspecific structural proteins, including glial fibrillary acidic protein (GFAP) and the neurofilament triplet proteins (Rami \& Rabie 1988, Ghosh et al. 1999).

In contrast, the influence of maternal $\mathrm{TH}$ on fetal brain development is poorly characterised. Adult progeny of thyroidectomised rat dams exhibit locomotor and learning dysfunction (Hendrich et al. 1984, Attree et al. 1992) and fetal brain growth is impaired in such models (Morreale de Escobar et al. 1985, Porterfield \& Hendrich 1991, Pickard et al. 1993). Although brain weight normalises after the onset of fetal TH synthesis in moderately hypothyroid dams (Pickard et al. 2000), neuronal maturation is impaired (Ruiz de Elvira et al. 1988, Pickard et al. 1993, Evans et al. 1999), and long-term changes occur to oligodendroglial and myelin metabolic markers (Hadjzadeh et al. 1990). In addition, iodine deficiency during pregnancy decreases GFAP expression in radial glia of the fetal hippocampus near term (Martinez-Galan et al. 1997).

In order better to understand the influence of maternal thyroid dysfunction on early fetal brain development, a partially thyroidectomised rat dam model was utilised to 
Table 1 Maternal serum thyroid hormone levels, litter size and fetal growth in euthyroid $(\mathrm{N})$ and partially thyroidectomized (TX) rat dam pregnancies

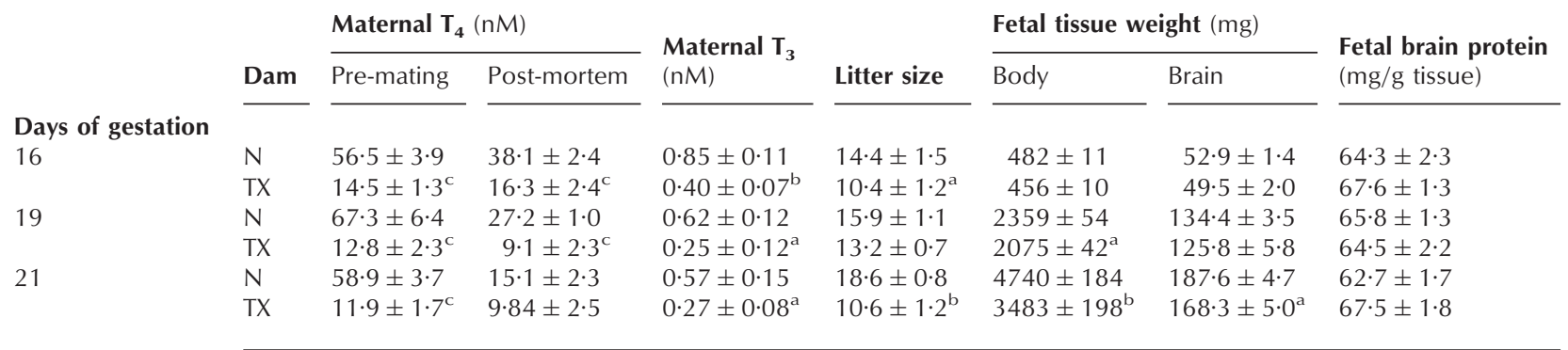

${ }^{\mathrm{a}} P<0 \cdot 05,{ }^{\mathrm{b}} P<0 \cdot 01,{ }^{c} P<0 \cdot 001, \mathrm{TX}$ compared with $\mathrm{N}$ dam pregnancy (Fisher's PLSD test; $n \geq 7$ different pregnancies).

evaluate the expression of cytoskeletal proteins immediately before and after the onset of fetal $\mathrm{TH}$ secretion, which occurs at 17.5 days gestation $(\mathrm{dg})$ in the rat (Morreale de Escobar et al. 1985). The cytoskeletal proteins investigated included the intermediate filament (IF) protein vimentin, expressed in early immature neurons and glia (Dahl et al. 1981, Bignami et al. 1982); GFAP, the predominant IF protein of mature astrocytes (Eng 1985); $\alpha$-internexin, an early axonal type IV IF protein expressed in developing CNS neurons, and the low molecular weight neurofilament protein (NF-L), expressed in developing neurons subsequent to $\alpha$-internexin (Kaplan et al. 1990).

\section{Materials and Methods}

\section{Materials}

Monoclonal antibodies against vimentin (clone V9), GFAP (clone G-A-5) and NF-L (clone NR-4) were from Sigma Chemical Co. Ltd (Poole, Dorset, UK); the $\alpha$-internexin monoclonal antibody was from Chemicon International (Harrow, UK). Rainbow protein molecular weight markers, Hybond enhanced chemiluminescence (ECL) nitrocellulose membrane, secondary antibody (anti-mouse immunoglobulin, horseradish peroxidase linked whole antibody from sheep; NA 931) and ECL Western blotting detection reagents were from Amersham Pharmacia Biotech UK Ltd (Little Chalfont, Bucks, UK). Coomassie Protein Plus reagent and bovine serum albumin standard were from Pierce (Chester, Cheshire, UK). The total $\mathrm{T}_{4}$ RIA kit was from NETRIA (London, UK) and the total 3,5,3'- tri-iodothyronine $\left(\mathrm{T}_{3}\right)$ RIA kit was from Brownes UK Ltd (Calcot, Reading, Berks, UK).

\section{Animal model}

Sprague-Dawley rats were housed at $22^{\circ} \mathrm{C}$ on a $14 \mathrm{~h}$ light and $10 \mathrm{~h}$ darkness cycle. Female rats were partially surgically thyroidectomised (parathyroid-spared; TX) and allowed to recover for 2 weeks, then mated with normal males when total serum $\mathrm{T}_{4}$ levels were $\leq 25 \mathrm{nM}$. Agematched pregnant normal $(\mathrm{N})$ females were the control group. Animals were maintained on an iodine replete $(13 \mu \mathrm{g} / \mathrm{g})$ standard small laboratory animal diet and drinking water for TX dams was supplemented with $0 \cdot 1 \%$ $(\mathrm{w} / \mathrm{v})$ calcium lactate. Pregnant animals were stunned then killed by cervical dislocation at 16, 19 or $21 \mathrm{dg}$ and maternal blood collected by cardiac puncture. Fetuses and placentae were separated on ice, and fetal brains quickly dissected, freed of blood and meninges, weighed, and 5-7 brains from each litter pooled. Maternal brain was also collected from a control dam for use as an immunoblotting standard. All tissues were stored at $-20{ }^{\circ} \mathrm{C}$. Animals were handled within local regulations and the Animals (Scientific Procedures) Act 1986.

\section{Sample preparation and Western blotting}

Brains were homogenised with 9 vol TE buffer $(2 \mathrm{mM}$ EDTA, $0.5 \% \mathrm{v} / \mathrm{v}$ Triton $\mathrm{X}-100$ and $10 \mathrm{mM}$ phenylmethylsulphonylfluoride in $50 \mathrm{mM}$ Tris $-\mathrm{HCl}$; $\mathrm{pH} 6 \cdot 8$ ), diluted to the required protein concentration with TE buffer, then boiled for 3 min under reducing conditions (Laemmli 1970). After SDS-PAGE, samples were electrophoretically transferred $\left(2 \mathrm{~h} ; 0.36 \mathrm{~A} ; 4{ }^{\circ} \mathrm{C}\right)$ to nitrocellulose membranes (Towbin et al. 1979).

Blots were blocked with $10 \%(\mathrm{w} / \mathrm{v})$ dried milk powder in TBS-T $(0 \cdot 1 \% \mathrm{v} / \mathrm{v}$ Tween-20 in Tris-buffered saline; $\mathrm{pH} 7 \cdot 6$ ) for $1 \mathrm{~h}$ at $25^{\circ} \mathrm{C}$, before incubation with either anti-GFAP, anti-vimentin, anti- $\alpha$-internexin or antiNF-L antibodies (diluted in blocking solution at 1:20 000, 1:2000, 1:5000 and 1:2000 respectively) for $1 \mathrm{~h}$ at $25^{\circ} \mathrm{C}$. Blots were washed in TBS-T before incubation for $1 \mathrm{~h}$ with secondary antibody (diluted 1:1000). After further washing with TBS-T, blots were processed using the manufacturers' ECL protocol, and exposed to pre-flashed film. Blots were stained with India Ink (Hancock \& Tsang 1983 ) in order to confirm equal sample loading.

Images of autoradiograms were captured using a Kodak DC40 digital camera and the band intensities estimated 
A
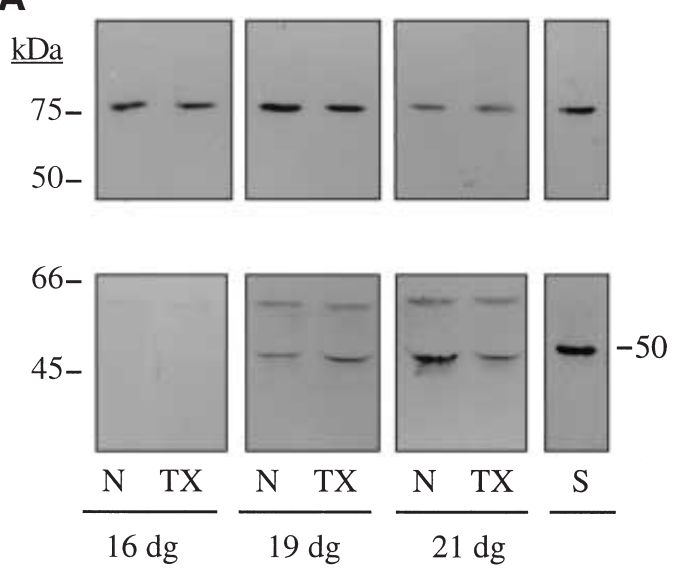

B

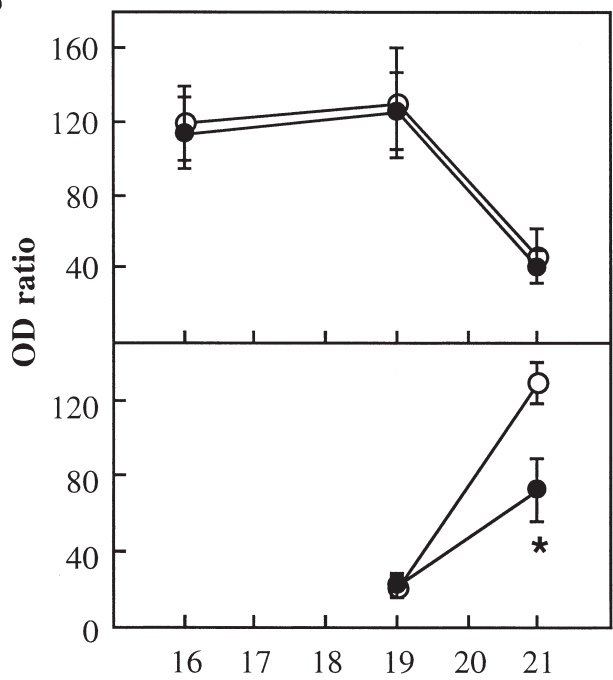

Days gestation

C

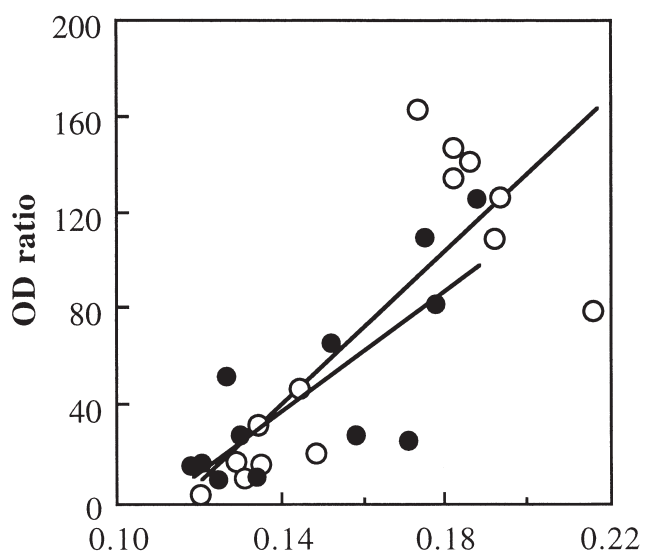

Fetal brain weight $(\mathrm{g})$ using NIH Image software calibrated with an optical density (OD) step tablet. Sample bands were corrected for filter-to-filter variation using standard signals by application of the correction factor $\left[\mathrm{x} / \mathrm{S}_{\text {ave }}\right] \cdot \mathrm{S}_{\text {filt }}$, where $\mathrm{x}$ is the OD of the sample band; $S_{\text {ave }}$ is the average OD of standards on all filters and $\mathrm{S}_{\text {filt }}$ is the $\mathrm{OD}$ of the standard on the same filter as the sample band $(\mathrm{x})$.

\section{Protein determination}

Protein was determined by a dye-binding method (Bradford 1976).

\section{Determination of maternal thyroid hormone levels}

Maternal serum total $\mathrm{T}_{4}$ and total $\mathrm{T}_{3}$ levels were determined by radioimmunoassays according to manufacturers' protocols.

\section{Statistical analysis and linear regression}

Data from $\mathrm{N}$ and TX dam pregnancies were compared by two-way ANOVA using Fisher's protected least significant difference (PLSD) test for post-hoc analysis. Homogeneity of variance for all groups was verified using Bartlett's test for samples of unequal sizes and, where appropriate, a square root or log transformation was applied before statistical analysis. All values are expressed as means \pm s.E.M. The relationship between cytoskeletal protein level and fetal brain weight was evaluated by linear regression analysis.

\section{Results}

\section{Animal model}

Pre-mating serum total $\mathrm{T}_{4}$ levels in TX dams were reduced to $20-25 \%$ of controls (Table 1). During late

Figure 1 The expression of vimentin and GFAP in fetal brain from normal $(\mathrm{N})$ and partially thyroidectomized (TX) rat dams. (A) Representative portions of Western blots probed with vimentin (upper panels) and GFAP (lower panels) antibodies. Vimentin blots contained samples and a $16 \mathrm{dg}$ normal fetal brain standard (S), all at $2 \cdot 5 \mu \mathrm{g}$ protein loading. GFAP blots contained samples (10 $\mu \mathrm{g}$ protein) and an adult brain standard (S; $0.25 \mu$ g protein). Migration of molecular weight markers is indicated on the left and authentic GFAP on the right. The GFAP antibody cross-reacts with a minor $60 \mathrm{kDa}$ protein species, which was not studied further. (B) Ontogenic profiles of vimentin (upper panel) and GFAP (lower panel). Each point is the mean \pm S.E.M. Of at least six different $N$ (open symbols) or TX (closed symbols) dams. Significant treatment $(P<0.05)$ and age-treatment $(P<0.05)$ effects were found for GFAP; ${ }^{*} P<0 \cdot 01$, TX compared with $N$ dam (Fisher's PLSD). (C) Regression of GFAP levels on fetal brain weight; the linear relationships found for $\mathrm{N}$ (open symbols) $\left(r^{2}=0.64 ; P=0 \cdot 0006\right)$ and for TX (closed symbols) $\left(r^{2}=0.61 ; P=0.0026\right)$ dams were not significantly different in slope or elevation. 
pregnancy, differences in maternal $\mathrm{T}_{4}$ levels between $\mathrm{N}$ and TX dams were less marked (Table 1), largely due to the expected decline in circulating $\mathrm{T}_{4}$ in $\mathrm{N}$ dams (Morreale de Escobar et al. 1985). Maternal serum total $\mathrm{T}_{3}$ was also reduced in TX dams, to between $40-50 \%$ of control levels (Table 1). TX dams carried fewer fetuses than $\mathrm{N}$ dams, and fetal body weights were reduced at 19 and $21 \mathrm{dg}$ to $88 \%$ and $73 \%$ of control levels respectively. Fetal brain weight was also reduced ( $90 \%$ of controls) in TX dams at $21 \mathrm{dg}$, but fetal brain protein concentration was normal at all ages (Table 1). Placental weight was also normal at all ages (data not shown).

\section{Vimentin expression}

The vimentin antibody recognised a single $57 \mathrm{kDa}$ band in fetal brain (Fig. 1), as expected (Fliegner \& Liem 1991). The abundance of vimentin remained constant between 16 and $19 \mathrm{dg}$, and decreased $(P<0 \cdot 01)$ markedly thereafter (Fig. 1). Maternal thyroidectomy was without effect on vimentin levels in fetal brain.

\section{GFAP expression}

The GFAP antibody recognised a $50 \mathrm{kDa}$ protein species, as expected, and a less abundant slower migrating species (ca. $60 \mathrm{kDa}$ ) in fetal and adult brain (Fig. 1). The $50 \mathrm{kDa}$ band was specific for nervous tissue, whereas the $60 \mathrm{kDa}$ band was detected in fetal liver, lung and heart (data not shown) and was therefore not studied further. GFAP was undetectable at $16 \mathrm{dg}$, but present at similar abundance in both groups at $19 \mathrm{dg}$. Levels increased fivefold between 19 and $21 \mathrm{dg}$ in $\mathrm{N}$ dam progeny, but only threefold in TX dam progeny. Consequently, GFAP was markedly deficient in TX fetal brain at $21 \mathrm{dg}$ (44\% of control level). Since fetal brain weight was also reduced at this age in TX dam progeny, we compared the relationship between GFAP abundance and brain weight between 19 and $21 \mathrm{dg}$ in both groups. Regression of GFAP on fetal brain weight resulted in superimposable regression lines (Fig. 1), indicating appropriate GFAP expression for fetal brain weight in TX dam progeny.

\section{a-Internexin expression}

The $\alpha$-internexin antibody recognised the expected $66 \mathrm{kDa}$ species in fetal and adult brain (Fliegner \& Liem 1991) (Fig. 2). In $\mathrm{N}$ fetal brain, abundance declined $(P<0 \cdot 01)$ between 16 and $19 \mathrm{dg}$ and then remained stable. Maternal thyroidectomy was associated with reduced levels at $16 \mathrm{dg}$ ( $71 \%$ of control value), but increased levels of expression at $21 \mathrm{dg}$ (147\% of control value). $\alpha$-Internexin abundance exhibited an inverse linear relationship with fetal brain weight in $\mathrm{N}$ dams throughout
A

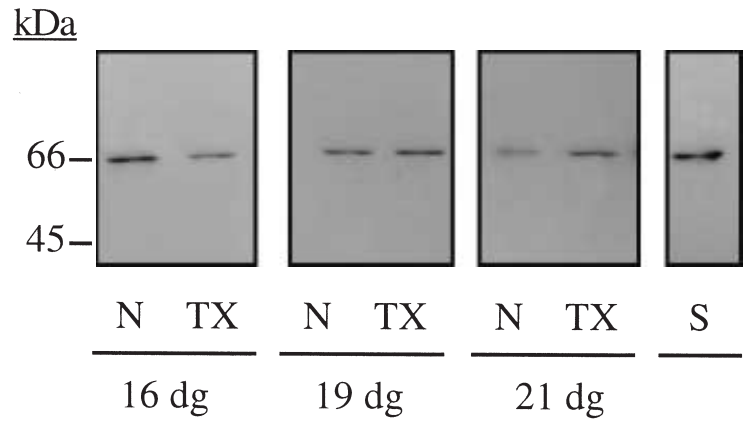

B

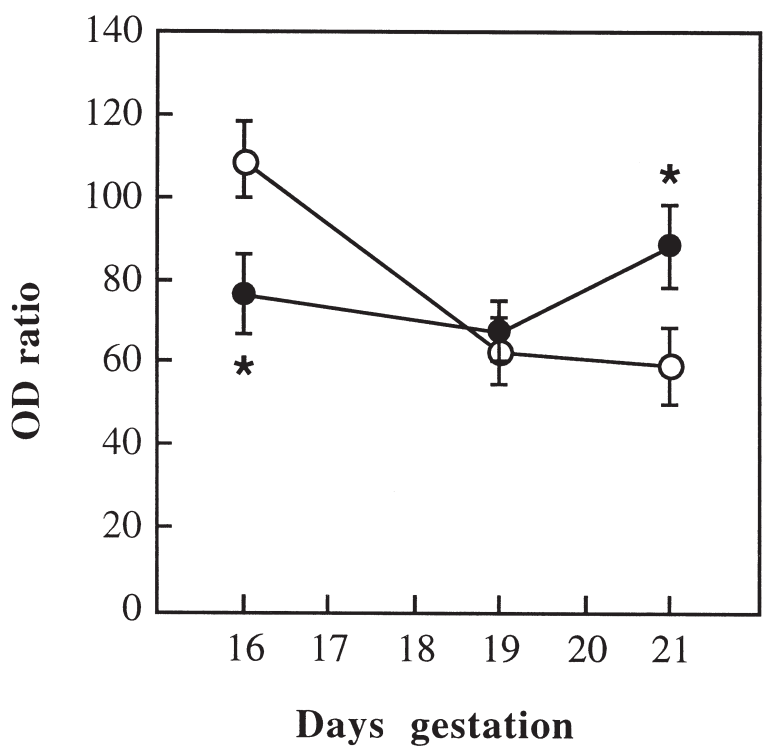

Figure 2 The expression of $\alpha$-internexin in fetal brain from normal $(\mathrm{N})$ and partially thyroidectomized (TX) rat dams. (A) Representative portions of Western blots containing samples and an adult brain standard (S) all at $2.5 \mu \mathrm{g}$ protein loading. Migration of molecular weight markers is indicated on the left. (B) Ontogenic profile of $\alpha$-internexin. Each point is the mean \pm S.E.M. of at least seven different $\mathrm{N}$ (open symbols) or TX (closed symbols) dam pregnancies. A significant age-treatment interaction occurred $(P<0 \cdot 01) .{ }^{*} P<0 \cdot 05$, TX compared with $\mathrm{N}$ dam (Fisher's PLSD).

the study period $\left(P=0 \cdot 0008, r^{2}=0 \cdot 4\right)$, but was unrelated to fetal brain weight in TX dams (data not shown).

\section{NF-L expression}

The NF-L antibody recognised a $68 \mathrm{kDa}$ species in fetal and adult brain (Fig. 3) as expected (Fliegner \& Liem 1991), the abundance of which increased $(P<0 \cdot 05)$ 
between 16 and $19 \mathrm{dg}$ in both $\mathrm{N}$ and TX dam progeny. Maternal thyroidectomy resulted in deficient expression of

A

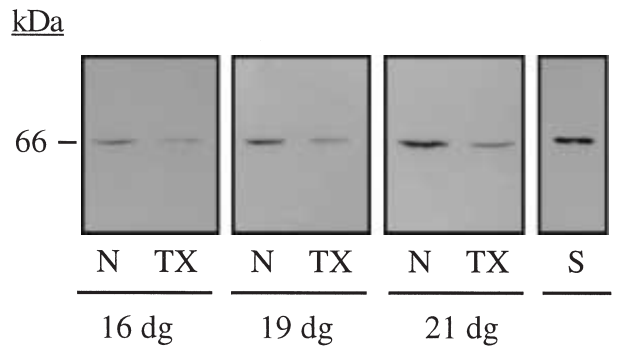

B

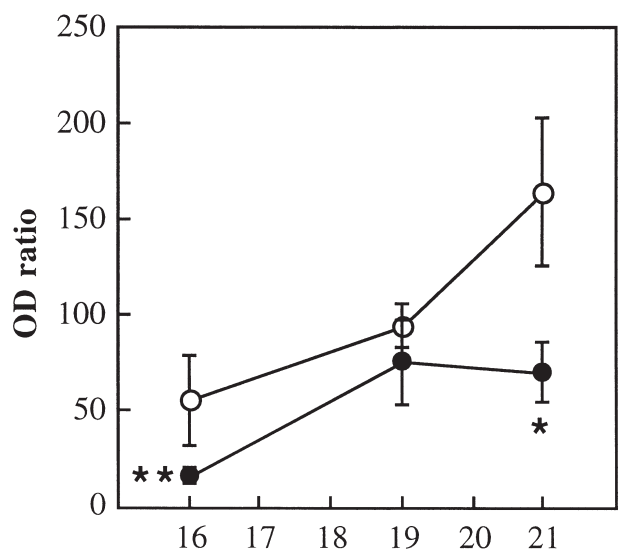

C

Days gestation

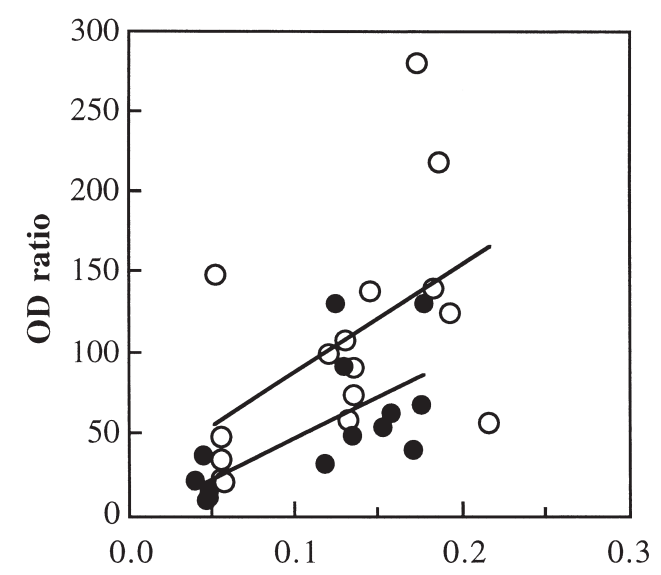

Fetal brain weight $(\mathrm{g})$
NF-L at $16 \mathrm{dg}$ (39\% of control level) and $21 \mathrm{dg}$ (43\% of control level). Regression of NF-L levels on fetal brain between 16 and $21 \mathrm{dg}$, revealed linear relationships in $\mathrm{N}$ and TX dam progeny of identical slope but differing elevation (Fig. 3). Thus, for a given fetal brain weight, NF-L levels were lower in TX than $\mathrm{N}$ dam progeny.

\section{Discussion}

Partial thyroidectomy depressed pre-mating maternal serum total $\mathrm{T}_{4}$ to around one quarter of control levels and was associated with a reduction in litter size. Fetal body and brain weights were depressed close to term, but placental weights were normal, consistent with previous studies of severely hypothyroid dams (Morreale de Escobar et al. 1985). In moderate maternal hypothyroxinaemia (pre-mating total $\mathrm{T}_{4}>16 \cdot 2 \mathrm{nM}$ ), however, late fetal growth appears normal (Pickard et al. 2000).

Vimentin is the predominant IF protein in several neuronal and astrocytic precursors. Maternal hypothyroidism had no effect on vimentin expression in fetal brain over the study period, indicating normal acquisition of neuronal and astrocytic precursor cells.

GFAP was detectable only after the onset of fetal TH secretion; levels were initially normal at $19 \mathrm{dg}$, but markedly deficient at $21 \mathrm{dg}$ in TX dam progeny. This indicates that maternal hypothyroidism impairs astrocytic maturation in the fetal brain towards the end of pregnancy. Models of combined materno-fetal hypothyroidism have shown that vimentin expression appears normal, but GFAP levels are reduced in perinatal hippocampus (Rami \& Rabie 1988, Martinez-Galan et al. 1997).

Although materno-fetal $\mathrm{T}_{4}$ transfer may contribute as much as one fifth of the fetal extrathyroidal $\mathrm{T}_{4}$ pool at $21 \mathrm{dg}$ (Morreale de Escobar et al. 1990), the onset of fetal secretion rapidly corrects fetal cerebral thyroid hormone deficits in overtly hypothyroid rat dams (Morreale de Escobar et al. 1985). Consequently, fetal brain hypothyroidism is unlikely to account for the GFAP deficit in TX dam progeny. Rather, this latter effect appears related to the retarded fetal brain growth, since TX dam fetuses express appropriate levels of GFAP for fetal brain weight.

Figure 3 The expression of NF-L in fetal brain from normal $(\mathrm{N})$ and partially thyroidectomized (TX) rat dams. (A) Representative portions of Western blots containing samples ( $10 \mu \mathrm{g}$ protein) and an adult brain standard ( $; ; 0.5 \mu \mathrm{g}$ protein). Migration of molecular weight markers is indicated on the left. (B) Ontogenic profile of NF-L. Each point is the mean \pm S.E.M. of at least 5 different $N$ (open symbols) or TX (closed symbols) dams. A significant $(P<0 \cdot 001)$ treatment effect was found: ${ }^{*} P<0 \cdot 05 ;{ }^{*} P<0 \cdot 01$, TX compared with $\mathrm{N}$ dam (Fisher's PLSD). (C) Regression of NF-L levels on fetal brain weight. The linear relationships found for $N$ (open symbols) $\left(r^{2}=0 \cdot 27 ; P=0 \cdot 038\right)$ and TX (closed symbols) $\left(r^{2}=0 \cdot 47 ; P=0 \cdot 0051\right)$ dams had identical slopes but different $(P<0 \cdot 05)$ elevations. 
$\alpha$-Internexin is the first neuronal intermediate filament to be expressed in newly differentiating neurons and constitutes the major neuronal IF protein prior to the onset of fetal thyroid hormone secretion. To our knowledge, the influence of thyroid status on $\alpha$-internexin expression has not previously been investigated, despite its suggested role in the stabilisation of small calibre axons during early brain development (Fliegner et al. 1994). Maternal hypothyroidism was associated with a deficit in $\alpha$-internexin abundance at $16 \mathrm{dg}$ and the absence of the expected ontogenic decline of this protein during late fetal life. Consequently $\alpha$-internexin levels were markedly elevated in TX fetal brain near term. This may have serious consequences if not corrected soon after birth, since over-expression of $\alpha$-internexin is associated with motor coordination deficits in transgenic mice (Ching et al. 1999). Ornithine decarboxylase and DOPA decarboxylase also have important roles in the acquisition of sensorimotor functions, and it is of some interest that they display comparable ontogenic profiles to $\alpha$-internexin in normal fetal brain and are similarly disturbed as a consequence of maternal hypothyroxinaemia (Pickard et al. 1993, Evans et al. 1999).

NF-L is expressed subsequent to $\alpha$-internexin during early neuronal differentiation (Kaplan et al. 1990, Fliegner et al. 1994). Maternal hypothyroidism was associated with reduced NF-L expression in fetal brain, both before the onset of fetal thyroid function and near term. Although $\mathrm{N}$ and TX dam progeny displayed similar rates of increase of NF-L with fetal brain weight, the elevations of these profiles were distinct. Consequently, NF-L levels in TX dam progeny were approximately half those in their normal counterparts for a given fetal brain weight.

The early deficit in NF-L is consistent with the recent report that thyroid hormone positively regulates NF-L expression in postnatal rat brain (Ghosh et al. 1999). However, the early deficit in $\alpha$-internexin expression may also be influential, as this protein is thought to form the primary scaffold around which neurofilament triplet proteins co-assemble during development (Fliegner et al. 1994, Balin \& Miller 1995, Ching \& Liem 1998).

Together, these findings suggest that maternal hypothyroidism in the rat disrupts early stages of neuronal differentiation in fetal brain, and that such disturbances are not corrected by the onset of fetal thyroid hormone secretion. Astrocytic differentiation - although initially normal - is perturbed near term concomitant with a more general delay in fetal brain growth. These findings confirm the existence of a critical period of maternal thyroid hormonedependency for fetal brain development (Pickard et al. 1997), be it mediated directly (through interaction with fetal brain TH nuclear receptors) or indirectly, at the levels of maternal metabolism and/or placental function (Bonet \& Herrera 1988, Hendrich \& Porterfield 1992, Leonard et al. 1999, Pickard et al. 1999, 2000).
Disruption of the co-ordinate maturation of neuronal and glial cells is likely to impinge upon the establishment of vital neural connections (Rakic 1990), possibly contributing to the behavioural deficits in postnatal progeny of hypothyroid rat dams (Attree et al. 1992, Sinha et al. 1997). The human brain at birth corresponds to the rat brain at 10 postnatal days so that most neuronal differentiation occurs prenatally in man but postnatally in rats (Porterfield \& Hendrich 1993). Studies in humans have emphasised the importance of the maternal $\mathrm{TH}$ environment prior to the onset of fetal thyroid function (18-20 weeks gestation in humans) with respect to fetal brain development (Connolly \& Pharoah 1989, Pop et al. 1999). a-Internexin, NF-L and GFAP are expressed in human fetal brain from at least 9 weeks gestation (Voronina \& Preobrazhensky 1994, Arnold \& Trojanowski 1996). Thus, similar compromise to that seen in the rat may contribute to the cognitive and motor dysfunction seen in the offspring of hypothyroid women (Connolly \& Pharoah 1989, Man et al. 1991, Haddow et al. 1999). However, given the differences in materno-fetal TH economy and placentation between rats and humans, extrapolations between these two species must be approached with sufficient caution.

The evidence presented here, together with previous studies, demonstrates that maternal thyroid status influences several developmental parameters in fetal brain. Experiments in progress in our laboratory aim to elucidate the spatial changes and molecular mechanisms underlying this regulation.

\section{Acknowledgement}

This work was partly funded by a grant from Action Research.

\section{References}

Arnold SE \& Trojanowski JQ 1996 Human fetal hippocampal development. II. The neuronal cytoskeleton. Journal of Comparative Neurology 367 293-307.

Attree E, Sinha AK, Davey M, Pickard MR, Rose F \& Ekins RP 1992 Effects of maternal hypothyroxinemia on activity, emotional responsiveness and exploratory behavior in adult rat progeny. Medical Science Research 20 197-199.

Balin BJ \& Miller ME 1995 Reassembly of the $66 \mathrm{kD}$ neurofilament protein in vitro following isolation and purification from bovine spinal cord. Journal of Neuroscience Research 40 79-88.

Bernal J \& Nunez J 1995 Thyroid hormones and brain development. European Journal of Endocrinology 133 390-398.

Bignami A, Raju T \& Dahl D 1982 Localisation of vimentin, the nonspecific intermediate filament protein, in embryonal glia and in early differentiating neurons. Developmental Biology 91 286-295.

Bonet B \& Herrera E 1988 Different response to maternal hypothyroidism during the first and second half of gestation in rat Endocrinology 122 450-455.

Bradford M 1976 A rapid and sensitive method for the quantification of microgram quantities of protein utilizing the principle of protein-dye binding. Analytical Biochemistry 72 248-254. 
Ching GY \& Liem RKH 1998 Roles of head and tail domains in $\alpha$-internexin's self assembly and coassembly with the neurofilament triplet proteins. Journal of Cell Science 111 321-333.

Ching GY, Chien CL, Flores R \& Liem RKH 1999 Overexpression of $\alpha$-internexin causes abnormal neurofilamentous accumulations and motor coordination deficits in transgenic mice. Journal of Neuroscience 19 2974-2986.

Connolly KJ \& Pharoah POD 1989 Iodine deficiency, maternal thyroxine levels in pregnancy and developmental disorders in the children. In Iodine and the Brain, pp 317-331. Eds GR Delong, JR Robbins \& PG Condliffe. New York: Plenum Press.

Dahl D, Reuger DC, Bignami A, Weber K \& Osborn M 1981 Vimentin, the 57000 molecular weight protein of fibroblast filaments is the major cytoskeletal component in immature glia. European Journal of Cell Biology 24 191-196.

Eng LF 1985 Glial fibrillary acidic protein (GFAP): the major protein of glial intermediate filaments in differentiated astrocytes. Journal of Neuroimmunology 8 203-214.

Evans IM, Sinha AK, Pickard MR, Edwards PR, Leonard AJ \& Ekins RP 1999 Maternal hypothyroxinemia disrupts neurotransmitter metabolic enzymes in developing brain. Journal of Endocrinology 161 273-279.

Fliegner KH \& Liem RK 1991 Cellular and molecular biology of neuronal intermediate filaments. International Review of Cytology 131 109-167.

Fliegner KH, Kaplan MP, Wood TL, Pintar JE \& Liem RKH 1994 Expression of the gene for the neuronal intermediate filament protein alpha internexin coincides with the onset of neuronal differentiation in the developing rat nervous system. Journal of Comparative Neurology 342 161-173.

Ghosh S, Rahaman Sk O \& Sarkar PK 1999 Regulation of neurofilament gene expression by thryoid hormone in the developing rat brain. Neuroreport 10 2361-2365.

Haddow JE, Palomaki GE, Allan WC, Williams JR, Knight GJ, Gagnon J, O'Heir CE, Mitchell ML, Hermos RJ, Waisbren S, Faix JD \& Klien RZ 1999 Maternal thyroid deficiency during pregnancy and subsequent neuropsychological development of the child. New England Journal of Medicine 341 549-555.

Hadjzadeh M, Sinha AK, Pickard M \& Ekins RP 1990 Effect of maternal hypothyroxinemia in the rat on brain biochemistry in adult progeny. Journal of Endocrinology 124 387-396.

Hancock K \& Tsang VCM 1983 India ink staining of proteins on nitrocellulose paper. Annals of Biochemistry 133 157-162.

Hendrich \& Porterfield 1992 Serum growth hormone levels in hypothyroid and GH-treated thyroidectomized rats and their progenies. Proceedings of the Society for Experimental Biology and Medicine 201 296-302.

Hendrich CE, Jackson W \& Porterfield S 1984 Behavioural testing of progenies of TX (hypothyroid) and growth hormone-treated TX rats; an animal model for mental retardation. Neuroendocrinology 38 429-437.

Kaplan MP, Chin S, Fliegner K \& Liem RKH 1990 Alpha internexin, a novel neuronal intermediate filament protein, precedes the low molecular weight neurofilament protein (NF- L) in the developing rat brain. Journal of Neuroscience 10 2735-2748.

Laemmli UK 1970 Cleavage of structural proteins during the assembly of the head of bacteriophage T4. Nature 227 680-685.

Leonard AJ, Pickard MR, Sinha AK, Edwards PR, Evans IM \& Ekins RP 1999 Maternal thyroid dysfunction and c-Fos and c-Jun expression in rat placenta. Placenta $20727-731$.

Man EB, Brown JF \& Serunian SA 1991 Maternal hypothyroxinemia; psychoneurological deficits of progeny. Annals of Clinical and Laboratory Science 21 227-239.

Martinez-Galan JR, Pedraza P, Santacana M, Escobar del Rey F, Morreale de Escobar G \& Ruiz-Marcos A 1997 Early effects of iodine deficiency on radial glial cells of the hippoampus of the rat fetus. Journal of Clinical Investigation 99 2701-2709.
Morreale de Escobar G, Pastor R, Obregon MJ \& Escobar del Rey JF 1985 Effects of maternal hypothyroidism on the weight and thyroid hormone content of rat embryonic tissues before and after the onset of fetal thyroid function. Endocrinology 117 1890-1900.

Morreale de Escobar G, Calvo R, Obregon MJ \& Escobar Del Rey 1990 Contribution of maternal thyroxine to fetal thyroxine pools in normal rats near term. Endocrinology 126 2765-2767.

Morreale de Escobar G, Obregon MJ, Calvo R, Pedrazza P \& Escobar del Rey F 1997 Iodine deficiency, the hidden scourge; the rat model of human neurological cretinism. In Recent Research Developments in Neuroendocrinology - Thyroid Hormone and Brain Maturation, pp 55-70. Ed CE Hendrich. Trivandrum: Research Signpost.

Pickard MR, Sinha AK, Ogilvie L \& Ekins RP 1993 The influence of the maternal thyroid hormone environment during pregnancy on the ontogenesis of brain and placental ornithine decarboxylase activity in the rat. Journal of Endocrinology 139 205-212.

Pickard MR, Evans IM, Bandopadhyay R, Leonard AJ, Sinha AK \& Ekins RP 1997 Thyroid hormone action in rat brain from fetal to adult life. In Recent Research Developments in NeuroendocrinologyThyroid Hormone and Brain Maturation, pp 15-29. Ed CE Hendrich. Trivandrum: Research Signpost.

Pickard MR, Sinha AK, Ogilvie LM, Leonard AJ, Edwards PR \& Ekins RP 1999 Maternal hypothyroxinemia influences glucose transporter expression in fetal brain and placenta. Journal of Endocrinology 163 385-394.

Pickard MR, Sinha AK, Ogilvie LM, Leonard AJ \& Ekins RP 2000 Maternal thyroid status regulates placental and liver glycogen levels. Journal of Endocrinology 164 (Suppl) Abstract OC2.

Pop VJ, Kuijpens JL, Van Baar AL, Verherk G, Van Son MM, Vijlder JJ, Vulsma T, Wiersinga WM, Drexhage HA \& Vader HL 1999 Low maternal free thyroxine concentrations during pregnancy are associated with impaired psychomotor development in infancy. Clinical Endocrinology 50 149-155.

Porterfield SP \& Hendrich CE 1991 The thyroidectomized pregnant rat - an animal model to study fetal effect of maternal hypothyroidism. Advances in Experimental Medicine and Biology 29 107-132

Porterfield SP \& Hendrich CE 1993 The role of thyroid hormones in prenatal and neonatal neurological development - current perspectives. Endocrine Reviews 14 94-106.

Rakic P 1990 Principles of neural cell migration. Experentia 46 882-891.

Rami A \& Rabie A 1988 Effect of thyroid deficiency on the development of glia in the hippocampal formation of the rat: an immunocytochemical study. Glia $1337-345$.

Ruiz de Elvira MC, Sinha AK, Pickard MR, Ballabio M, Hubank M \& Ekins RP 1988 Effect of maternal hypothyroxinemia during fetal life on the calmodulin-regulated phosphatase activity in the brain of adult progeny in the rat. Journal of Endocrnology 121 331-335.

Sinha AK, Prakabaran D, Godbole MM, Chattopadhyay N, Karmarkar M, Pickard MR, Leonard AJ \& Ekins RP 1997 Thyroid hormones and the human fetal brain. In Recent Research Developments in Neuroendocrinology - Thyroid Hormone and Brain Maturation, pp 1-14. Ed CE Hendrich. Trivandrum: Research Signpost.

Towbin H, Staehlin T \& Gordon J 1979 Electrophoretic transfer of proteins from polyacrylamide gels to nitrocellulose sheets: procedure and some applications. PNAS 76 4350-4354.

Voronina AS \& Preobrazhensky AA 1994 Developmental expression of glial fibrillary acidic protein gene in human embryos. Neuroscience Letters 174 198-200.

Received 5 May 2000

Accepted 23 August 2000 